\section{Efficacy of a Hydrophilic Polymer Declines with Time in Greenhouse Experiments}

\author{
A.R. Al-Harbi ${ }^{1}$ \\ Department of Plant Production, King Saud University, College of Agriculture, \\ P.O. Box 2460, Riyadh 11451, Saudi Arabia
}

\author{
A.M. Al-Omran ${ }^{2}$, A.A. Shalaby ${ }^{3}$, and M.I. Choudhary ${ }^{4}$ \\ Department of Soil Science, King Saud University, College of Agriculture, \\ P.O. Box 2460, Riyadh 11451, Saudi Arabia
}

Additional index words. Cucumis sativus, soil water-holding capacity, bulk density, leaf area, shoot weight

\begin{abstract}
The effect of a hydrophilic polymer (Broadleaf P4 ${ }^{\circledR}$;P) on growth of cucumber seedlings (Cucumis sativus L.) was investigated. Furthermore, the efficiency of HP to absorb water over a period of time was studied. Predetermined amounts of HP $(0.0 \%$, $0.1 \%, 0.2 \%, 0.3 \%$, and $0.4 \%$ dry-weight basis) were mixed with moderately calcareous sandy loam soil in pots. At the end of the first experiment (42 days), the growth of the seedlings was recorded, as well as the maximum soil water-holding capacity (WHC). The same pots were left for a drying period ranging from 2 to 5 months and then used for another four successive experiments. Soil WHC increased significantly with increasing level of HP, but decreased after each experiment. After five experiments, the WHC had decreased $17.3 \%$ and $27.8 \%$ where HP was added at the rate of $0.1 \%$ and $0.4 \%$, respectively. The bulk density of soils decreased significantly with addition of $\mathrm{HP}$ and had increased after five growing experiments at each HP rate. Cucumber seedling growth was stimulated by addition of the polymer. The greatest vegetative growth, expressed as leaf area and shoot fresh and dry weights, was observed at $0.3 \% \mathrm{HP}$ in the first and second experiment, but at $0.4 \%$ in the third and fourth.
\end{abstract}

Research on hydrophilic polymers (HP) as soil amendments has been intensified in the last decade. Water-absorbing synthetic polymers may improve the properties of lighttextured soils and therefore stimulate plant growth. Addition of HP increases water-holding capacity (WHC) and reduces evaporation losses and can significantly increase water use efficiency (Al-Omran et al.,1987; Johnson, 1984). This improved water balance has stimulated seed germination and seedling growth (Al-Harbi et al., 1994; Janet and Hensley, 1986; Save et al., 1995). However, large-scale use of HP is still limited, especially in the field and in greenhouses. Salinity of soil and irrigation water, which is further enhanced by addition of fertilizers, reduces the hydration of HP (James and Richards, 1986; Lamont and Connell, 1987; Wang and Gregg, 1990). An-

Received for publication 26 Feb. 1998. Accepted for publication 4 Aug. 1998. Trademark Broadleaf P4 ${ }^{\circledR}$ does not constitute an official endorsement of the product, but rather is for the convenience of the reader. The cost of publishing this paper was defrayed in part by the payment of page charges. Under postal regulations, this paper therefore must be hereby marked advertisement solely to indicate this fact.

${ }^{1}$ Associate Professor; to whom reprint requests should be addressed.

${ }^{2}$ Professor.

${ }^{3}$ Research Associate.

${ }^{4}$ Lecturer. other limiting factor is the unknown duration of HP's beneficial effect in absorbing water. Little work has been done to measure the longterm breakdown rate of HP, which depends upon the rate and depth of application, weathering of soil, tillage operations, and many other factors (Seybold, 1994). Orzolek (1993) reported that degradation of HP appears to result from microorganisms, modification of physical structure, and chemical decomposition; as a result, HP lose $10 \%$ to $15 \%$ of their activity each year.

This study was designed to investigate the effect of HP, applied at several rates over a long period of time, on the growth of cucumber seedlings grown in pots under greenhouse conditions, and to measure its breakdown rate.

\section{Materials and Methods}

Five successive pot experiments were carried out over a period of 2 years (22 Apr. 1994 to 17 Apr. 1996). A bulk surface sample (25 $\mathrm{cm}$ ) from a calcareous sandy loam soil (Typic Torripsamments) was collected at the Agricultural Experimental Station of King Saud Univ. at Deirab. The soil was air-dried and passed through a 2-mm sieve. Soil properties, determined using standard procedures, were as follows: organic matter $(0.75 \%), \mathrm{CaCO}_{3}$ (28\%), pH (7.8), $\mathrm{EC}_{\mathrm{e}}\left(0.76 \mathrm{dS} \cdot \mathrm{m}^{-1}\right)$, sodium adsorption ratio $(8.1)$, clay (11\%), silt (12\%), and sand $(77 \%)$.
The HP (Broadleaf $\mathrm{P}^{\circledR}{ }^{\circledR}$; Agricultural Polymers Ltd., Gloucester, U.K.) used in this study is an insoluble, granular Na-polyacrylamide material. The required weights of polymer were hand-mixed with dried soil to give five concentrations on a dry-weight basis: 0 (control), $0.1 \%, 0.2 \%, 0.3 \%$, and $0.4 \%$. The treatments were replicated four times in a completely randomized design. Plastic pots $20 \mathrm{~cm}$ wide and $22 \mathrm{~cm}$ deep of 7-L volume were filled with $7 \mathrm{~kg}$ of treated soil. The pots were placed in a greenhouse at temperatures of $25^{\circ} \mathrm{C}$ day/ $18^{\circ} \mathrm{C}$ night.

Initially, all the pots were irrigated with predetermined amounts of municipal tap water $\left(\mathrm{EC}=0.38 \mathrm{dS} \cdot \mathrm{m}^{-1}\right)$ to bring the moisture content of the soils to field capacity. Five cucumber seeds were sown in each pot. The seedlings were thinned to one per pot at the second-leaf stage; thereafter, the pots were irrigated once a week with irrigation water containing dilute but well-balanced McLean and Gilbert nutrient solution-1, which is very low in divalent cations (Hewitt, 1966). Field capacity of the soil was determined at the beginning of each experiment using the smallcore method of Cassel and Nielsen (1986). The moisture lost was calculated by weighing the control (untreated soil) and this amount of water was added to each pot.

In the first experiment, the seeds were sown on 22 Apr. (0 day after mixing) and the experiment was ended on 7 June 1994. Four other experiments with similar growth conditions were carried out in the same pots, which were allowed to dry 2 to 5 months between experiments. The duration for the subsequent experiments were 21 Nov. 1994 to 8 Jan. 1995 (213 d after mixing); 1 Apr. to 3 May 1995 (344 d after mixing); 15 Oct. to 26 Nov. 1995 (541 d after mixing); and 5 Mar. to $17 \mathrm{Apr}$. 1996 (683 d after mixing). Leaf area and shoot fresh and dry weights were determined at the end of each growing period. The data were analyzed by analysis of variance, and least significant differences were calculated for each experiment.

The WHC was determined at the beginning of each experiment, prior to sowing the seeds, by using plastic rings $(40-\mathrm{mm}$ diameter). The rings were filled with soil $(\approx 25 \mathrm{~g})$ to a uniform compaction and half-immersed in deionized water for $24 \mathrm{~h}$ to obtain maximum saturation. Excess water was drained by placing the covered rings over glass funnels. After half an hour, the soils were weighed and mois-

Table 1. Effect of addition of hydrophilic polymer (HP) on bulk density of a calcareous soil at the beginning and at the end of Expts. 1-5.

\begin{tabular}{lcc}
\hline & \multicolumn{2}{c}{ Bulk density $\left(\mathrm{g} \cdot \mathrm{cm}^{-3}\right)$} \\
\cline { 2 - 3 } $\mathrm{HP}(\%)$ & Initial & Final \\
\hline 0.0 (Control) & 1.46 & 1.46 \\
0.1 & 1.36 & 1.35 \\
0.2 & 1.18 & 1.23 \\
0.3 & 1.00 & $1.12^{*}$ \\
0.4 & 0.90 & $1.07^{*}$ \\
$\mathrm{LSD}_{0.05}$ & 0.21 & 0.04 \\
\hline
\end{tabular}

*Significantly different from initial value at $P \leq 0.05$ by standard $t$ test. 


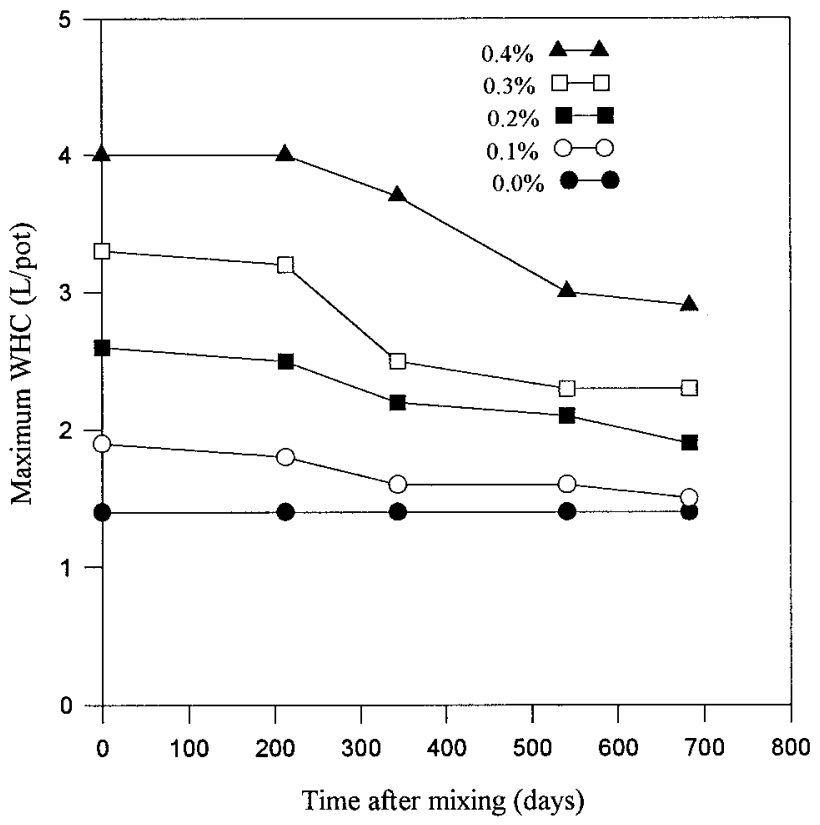

Fig. 1. Effect of hydrophilic polymer (0 to $0.4 \%$ ) on water-holding capacity (WHC) of soil during five greenhouse experiments.

ture was determined by the gravimetric method with oven drying (Choudhary et al., 1995).

Bulk density of all moist soil samples was determined at the beginning of each experiment by the core method of Blake and Hartge (1986).

\section{Results and Discussion}

The initial bulk density was reduced $6.8 \%$, $19.2 \%, 31.5 \%$, and $38.4 \%$ when soil was mixed with conditioner at rates of $0.1 \%, 0.2 \%, 0.3 \%$, and $0.4 \%$, respectively (Table 1 ). After the fifth experiment, these values were $7.5 \%$, $15.8 \%, 23.3 \%$, and $26.7 \%$, respectively. The initial soil bulk density at $0.3 \%$ and $0.4 \%$ rates of the polymer were significantly less than the final value; this may be attributed to the loss of effectiveness of the polymer with time, as reported by Choudhary et al. (1999).

Hydration of the soil decreased significantly during each experiment. For example,

Table 2. Linear regression and $r$ values of waterholding capacity (WHC) on number of experiments at several rates of hydrophilic polymer (HP).

\begin{tabular}{lccc}
\hline \hline HP $(\%)$ & \multicolumn{2}{c}{ Regression coefficient } & \multicolumn{1}{c}{$\begin{array}{c}\text { Correlation } \\
\text { coefficient }(r)\end{array}$} \\
\cline { 2 - 3 } 0 & $\mathrm{a}$ & $\mathrm{b}$ & --- \\
0.1 & --- & --- & -0.915 \\
0.2 & 1.909 & -0.084 & -0.984 \\
0.3 & 2.806 & -0.181 & -0.932 \\
0.4 & 3.615 & -0.292 & -0.909 \\
\hline
\end{tabular}

at the $0.1 \%$ polymer rate, the WHC was reduced, relative to that at the end of the first experiment, by $6.3 \%, 16.2 \%, 16.5 \%$, and $17.3 \%$ after the second, third, fourth, and fifth experiments (Fig. 1). However, these values increased with HP concentrations. Again, this reduction in WHC may be attributed to the loss of effectiveness of the polymer with time. This confirms the results previously reported by Orzolek (1993) that the polymers lose $10 \%$ to $15 \%$ of their activity each year. The $0.4 \%$ concentration produced the highest WHC values because of the hydrophilic nature of the synthetic conditioner.

In general, WHC decreased with each experiment at each HP rate. This relationship was linear, as shown by regression analysis (Table 2). The rate of change in soil maximum WHC with increasing number of experiments increased with HP rate.

In the first and second experiments, seedling growth was greater in treated soil (Table 3). As shown previously by Al-Harbi et al. (1996), the application rate of $0.3 \%$ was sufficient for maximum growth, as indicated by the leaf area, and the shoot fresh and dry weight. When the effectiveness of the HP decreased, as shown by the reduction in soil WHC after each experiment, a higher rate of polymer was required for maximum seedling growth. In the third and fourth experiments, HP efficiency had decreased $14.3 \%$ and $21.8 \%$ and the optimum rate for maximum seedling growth had increased. The highest leaf area, and shoot fresh and dry weight were obtained at the highest polymer rate $(0.4 \%)$. In the fifth experiment, seedling growth in the treated soil was higher than that in the control, but the difference between HPlevels was not consistent.

The results of the present work indicate that the efficacy of the HP under greenhouse conditions decreased $10 \%$ to $15 \%$ each year and a higher rate was required for maximum plant growth. A further study is needed to determine breakdown of HP over time under field conditions.

\section{Literature Cited}

Al-Harbi, A.R., A.M. Al-Omran, A.A.Shalaby, H. Wahdan, and M.I. Choudhary. 1996. Growth response of cucumber to hydrophilic polymer application under different soil moisture levels. J. Veg. Crop Prod. 2:57-61.

Al-Harbi, A.R., A.M. Al-Omran, H. Wahdan, and A.A Shalaby. 1994. Impact of irrigation regime and addition of a soil conditioner on tomato seedling growth. Arid Soil Res. and Rehabilitation 8:285-290.

Al-Omran, A.M., M.A. Mustafa, and A.A. Shalaby. 1987. Intermittent evaporation from soil columns as affected by gel-forming conditioner. Soil Sci. Soc. Amer. J. 51:1593-1599.

Blake, G.R. and H.K. Hartge. 1986. Bulk density, p. 363 376. In: A. Klute (ed.). Methods of soil analysis. Part 1. ASA-ASSS, Madison, Wis.

Cassel, D.K. and D.R. Nielsen, 1986. Field capacity and available water capacity, p. 901-926. In: A. Klute (ed.). Methods of soil analysis. Part 1. ASA-ASSS, Madison, Wis.

Choudhary, M.I., A.M.Al-Omran, and A.A. Shalaby. 1999. Physical properties of sandy soil affected by a soil conditioner under wetting and drying cycles. Sultan Qaboos Univ. J. Sci. Res. Agr. Sci. (In press.)

Choudhary, M.I., A.A. Shalaby, and A.M. Al-Omran. 1995. Water-holding capacity and evaporation of calcareous soils as affected by four synthetic polymers. Commun. Soil Sci. Plant Anal. 26:2205-2215.

Hewitt, E.J. 1966. The composition of the nutrient solution, p. 187-246. In: E.J. Hewitt (ed.). Sand and water culture methods used in the study of plant nutrition. Cmwlth. Agr. Bur., London.

James, E.A. and D. Richards. 1986. The influence of iron source on the water-holding properties of potting media amended with water-absorbing polymer. Scientia Hort. 28:201-208.

Janet, C.H. and D.L. Hensley. 1986. Efficacy of hydrophilic gel as a transplant aid. HortScience 21:991-992.

Johnson, M.S. 1984. Effect of soluble salts on water absorption by gel-forming soil conditioners. J. Sci. Food Agr. 35:1063-1066.

Lamont, G.P.and M.A. O'Connell. 1987. Shelf-life of bedding plants as influenced by potting media and hydrogel. Scientia Hort. 31:141-149.

Orzolek, M.D. 1993. Use of hydrophilic polymer in horticulture. HortTechnology 3:41-44

Save, R., M. Pery, O. Marafa, and L. Serrano. 1995. The effect of a hydrophilic polymer on plant water status and survival of transplanted pine seedlings. HortTechnology 5:141-143.

Seybold, C.A. 1994. Polyacrylamide review: Soil conditioning and environmental fate. Commun. Soil Sci. Plant Anal. 25:2171-2185.

Wang, Y.T. and L.L. Gregg. 1990. Hydrophilic polymersTheir response to soil amendments and effect on properties of soilless potting mix. J. Amer. Soc. Hort. Sci. 115:943-948.

Table 3. Effect of hydrophilic polymer (HP) on the growth of cucumber seedlings in five experiments.

\begin{tabular}{|c|c|c|c|c|c|c|c|c|c|c|c|c|c|c|c|c|}
\hline \multirow[b]{2}{*}{ HP (\%) } & \multirow[b]{2}{*}{ Expt.: } & \multicolumn{5}{|c|}{ Leaf area $\left(\mathrm{cm}^{2}\right)$} & \multicolumn{5}{|c|}{ Shoot fresh weight (g) } & \multicolumn{5}{|c|}{ Shoot dry weight (g) } \\
\hline & & 1 & 2 & 3 & 4 & 5 & 1 & 2 & 3 & 4 & 5 & 1 & 2 & 3 & 4 & 5 \\
\hline 0.1 & & 761 & 714 & 190 & 273 & 641 & 36.0 & 34.1 & 8.1 & 10.2 & 12.79 & 4.8 & 4.1 & 0.78 & 0.85 & 2.04 \\
\hline 0.4 & & 734 & 738 & 365 & 1382 & 651 & 37.9 & 33.4 & 15.6 & 66.1 & 12.74 & 5.3 & 4.2 & 1.64 & 5.18 & 2.53 \\
\hline $\mathrm{LSD}_{0.05}$ & & 88.8 & 94.5 & 57.5 & 231.1 & 161 & 4.1 & 4.7 & 3.2 & 10.3 & 2.6 & 0.7 & 0.6 & 0.3 & 0.7 & 0.65 \\
\hline
\end{tabular}

